Article

\title{
Application of Reliability Analysis for Risk Ranking in a Levee Reconstruction Project
}

\author{
Meho Saša Kovačević *, Lovorka Librić, Gordana Ivoš and Anita Cerić \\ Faculty of Civil Engineering, University of Zagreb, 10000 Zagreb, Republic of Croatia; llibric@grad.hr (L.L.); \\ givos@grad.hr (G.I.); anita@grad.hr (A.C.) \\ * Correspondence: msk@grad.hr; Tel.: +385-1-4639-650
}

Received: 10 January 2020; Accepted: 7 February 2020; Published: 14 February 2020

\begin{abstract}
Levees are embankments designed for passive flood protection. In order to reduce the potential of climate-induced flooding risks, it is necessary to reconstruct or upgrade the existing levees. Flood risk management aims to reduce the probability of floods and their potential adverse effects on the population, economy, and environment. This paper presents the novel application of reliability analysis for risk ranking in the Otok Virje-Brezje levee reconstruction project in the Republic of Croatia. To identify, verify and analyse key risks, a group of 35 experts, who were directly involved in the levee reconstruction project or have extensive experience in similar projects, was selected. An Analytic network process (ANP) was used for group multi criteria decision-making. Quantitative and qualitative approaches to risk analysis were combined. Different experts from the various organisations may have diverse interests and goals. The geometric mean method was chosen to reach group consensus. The resources that will be allocated to the risk responses are proportional to the risk exposures. To analyse the reliability of the group consensus-reaching method a determination of the risk ranking probability matrix is proposed by using the Monte Carlo simulation method. Different decision-making approaches are proposed for cases in which consensus is not reached with satisfactory reliability.
\end{abstract}

Keywords: levee; risk ranking; brainstorming technique; analytic network process (ANP); group decision making; reliability analysis

\section{Introduction}

A flood is the most disturbing natural incident that affects and disrupts the safety of a society, especially people who are vulnerable to disaster due to geographic conditions and poor available resources [1]. Floods can cause losses of human lives, extensive material damages, the devastation of cultural properties, population displacement and environmental damages, while significantly hampering economic development. Prognostic climate models indicate an increasing incidence of extreme climatic phenomena resulting most likely from climate change, both on a global and local level. Extreme air temperatures, rainfall intensities and dry periods can be expected in the future, along with the occurrence of storms and devastating winds. The consequences of climate change are evidenced by the increasing duration, intensity and frequency of floods, higher risks of riverine flooding, more frequent floods of occasional watercourses, and changed patterns of snow melting and ice flooding [2-5].

The regulation of watercourses, construction of levees and different operational measures such as setting up waterbeds in emergencies are all flood protection measures. Levees are embankments used for passive flood protection, aimed to prevent the consequences of flooding. They are regulation structures used outside the main riverbed. They are always in place and provide permanent flood protection without any action from the property owner. Levees protect the target area from high water 
levels [6,7]. In the Republic of Croatia, alongside the national watercourses, there are approximately $2400 \mathrm{~km}$ of levees. Among them, there are approximately $1600 \mathrm{~km}$ of levees of different levels of protection alongside local watercourses. A large number of these levees are in bad condition and need to be rebuilt or reconstructed. Other levees are not high enough to match extremely high levels of water. It is, therefore, necessary to build tops in order to meet the appropriate safety and functionality requirements $[8,9]$.

Floods are a natural phenomenon that cannot be prevented; however, the risk of flood-related adverse effects can be minimised. The impact of climate change on the hydrological behaviour of the river basin, both in natural and modified conditions, should be considered when managing flood risks, precisely because of possible changes in the flood regime. Changes in the intensity and frequency of extreme rainfall, combined with changes in land-use patterns, will lead to an increase in flood risk globally [10-12]. Risk management always starts with risk identification [13]. A list of risks relevant for a levee reconstruction project is compiled following in-depth research of the potential sources of risk, adverse events that include risk, and the unfavourable effects of an undesirable scenario. Risk identification, among other sociological and psychological factors, largely depends on experience [14-16].

Risk assessment is performed for each identified risk. There are two independent components of risk: the likelihood of the risk (risk probability) and the impact of the risk on the project (risk impact). These components must be quantified to analyse, compare, and prioritise various risks. This is accomplished by introducing the risk exposure that represents the product of the risk probabilities and the risk impact on the project: risk exposure $=$ risk probability $\times$ impact risk [17]. Risk exposure can be determined by one of the multi-criteria analysis methods. By determining risk exposure for all the identified risks and finding their interrelationship, a risk ranking list can be compiled. Depending on the position of the risk (relative value of its exposure with reference to the other risks) in the risk ranking list, resources can be used for the anticipated risk response [15].

Risk assessment can be performed by an individual or a group of experts. In the latter case, the main problem is aggregation of the preference rankings of individuals into reliable consensus ranking. Numerous aggregation methods have been proposed to solve this problem [18]. Liao et al. [19] proposed an enhanced consensus reaching process for group decision making, which removes some expert opinions instead of removing the expert from the decision group. Dong and Cooper [20] developed a peer-to-peer dynamic adaptive consensus reaching model based on an automatic feedback mechanism. However, the problem of reliability intensifies with an increase in the number of experts involved in the decision-making process. There will always be experts whose priorities are significantly different from the others and whose risk priority list will be significantly different from the aggregated list [21]. Xu et al. [22] developed an improved consensus model for large-group emergency decision-making. The model is designed to manage minority opinions and non-cooperative behaviors. Palomares et al. [23] proposed a consensus model suitable to manage large scales of decision-makers and capable of managing individual and subgroup noncooperative behaviors. The main issue is the reliability of a consensus ranking that represents an aggregated result. In order to analyse and measure the reliability of an expert in a group, Fu et al. [24] developed a group evidential reasoning approach where the weights and reliabilities of attributes and experts are included. Instead of dealing with the reliabilities of experts, this study presents a novel application of reliability analysis for risk ranking in a levee reconstruction project. Various methods can be used to aggregate the preference rankings of individuals into consensus ranking. The most used methods are: arithmetic mean [25], geometric mean [26], harmonic mean [27], Bonferroni mean [28], power [29], Choquet integral [30], Sugeno integral [31] and hybrid method [32]. Aczel and Saaty [33] showed that the best aggregation method for ANP is the geometric mean, so it was used to determine the risk exposures for each key risk. This means that risk exposures can be treated as random variables and that the reliability analysis of the ranking of a particular key risk in the risk priority list can be conducted. The risk ranking probability matrix was determined as a result, and its components included the probabilities that risk 
exposure of lower-ranking risk is higher than risk exposure of higher-ranking risk. The reliability analysis combines The Analytic Network Process (ANP) and Monte Carlo Simulation (MCS) method. If consensus is not able to be reached with satisfactory reliability, different decision-making approaches are proposed.

This study is structured as follows. Considering the fact that the risk exposure is site-specific, the following section describes the flooding and breaching, as well as the proposed reconstruction measures for the Otok Virje-Brezje levee, located in the northwest part of the Republic of Croatia. This project was chosen to demonstrate the applicability of the proposed methodology of reliability analysis for risk ranking in a levee reconstruction project. Section 3 shows the identification of the key risks that can exist during the levee reconstruction. Section 4 presents the risk assessment of the levee reconstruction project based on the analytic network process (ANP) model. Section 5 elaborates on a reliability analysis for risk ranking using the Monte Carlo simulation method. Section 6 discusses different decision-making approaches that can be applied in cases where consensus is not reached with satisfactory reliability. The final section presents the conclusions.

\section{Flooding, Breaching and the Reconstruction Design of the Otok Virje-Brezje Levee}

The Drava River levee of Otok Virje-Brezje was constructed in 1968 to protect all towns between Otok Virje and Varaždin from flooding. These towns have 815 houses and 3090 citizens, as well as approximately 450 ha of agricultural land and forests. The total length of the levee is $3711 \mathrm{~m}$. On 6 November, 2012, the Drava River basin in Austria experienced heavy rainfalls. As a result, the large flood wave moved from Austria through Slovenia to Croatia. The maximum water level of the flood wave exceeded the levee crest. The result was overtopping of the levee for $1000 \mathrm{~m}$ and breaching of the levee for a width of approximately $50 \mathrm{~m}$. The water stream formed a dent in the foundation soil on the offshore side of the levee with a depth of approximately $3.5 \mathrm{~m}$ (Figure 1).
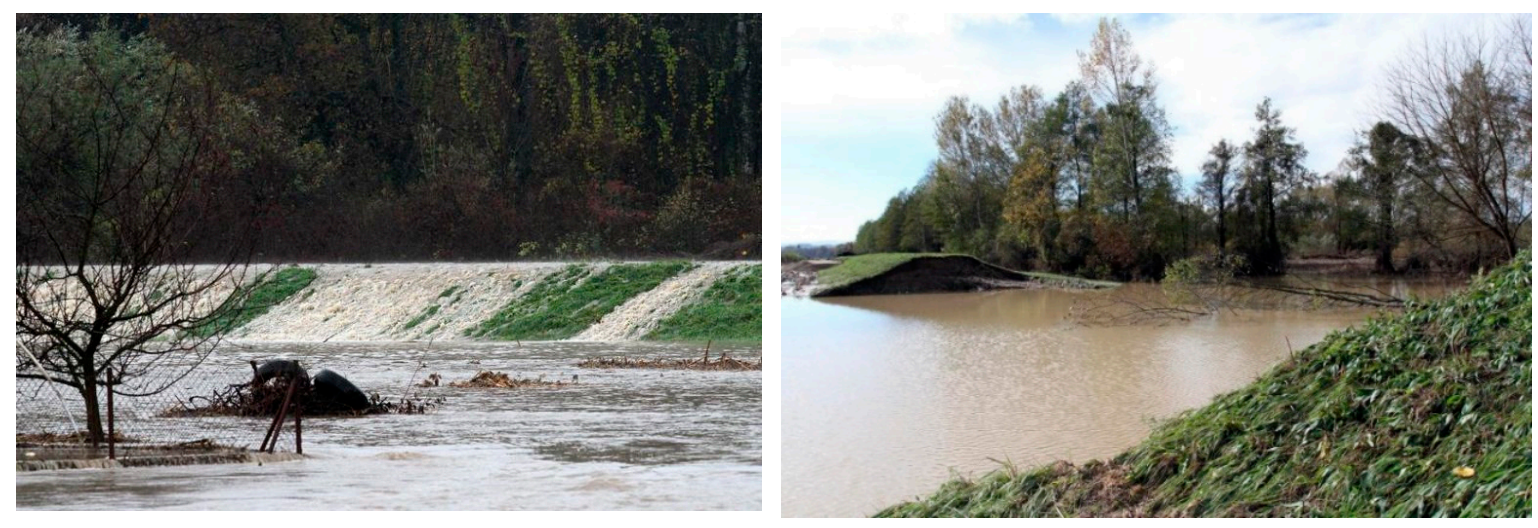

Figure 1. Overtopping and breach in Otok Virje-Brezje levee [34].

As a result, the towns of Otok Virje, Vratno Otok and Virje Križovljansko were flooded. A total of 90 houses and two commercial buildings were flooded; this includes roads Otok Virje-Križovljan Grad, Otok Virje-Vratno Otok, and Otok Virje-Virje Križovljansko. The total flooded area was approximately $645 \mathrm{~km}^{2}$ (Figure 2).

Considering that climate change implies higher likelihood and more frequent extreme water levels, a design for reconstruction has been prepared [34]. The new levee crest will be $0.5 \mathrm{~m}$ higher than the water level with a flow of $3100 \mathrm{~m}^{3} / \mathrm{s}$. The statistical level of water for the 100-year return period equals $3015 \mathrm{~m}^{3} / \mathrm{s}$. Given that the proposed material for the reconstruction is well-graded sand, and it does not meet the necessary water resistance requirements, a geosynthetic clay liner (GCL) will be built on the upstream side. It will be topped with a protective layer $(60 \mathrm{~cm})$ of material excavated for the foundation of the levee (Figure 2). A protection net will be placed on top of the protection layer, 
together with a $20 \mathrm{~cm}$ thick layer of humus and final hydrolysis. The stability of the slope will be achieved by installing three rows of single geogrids (Figure 3).

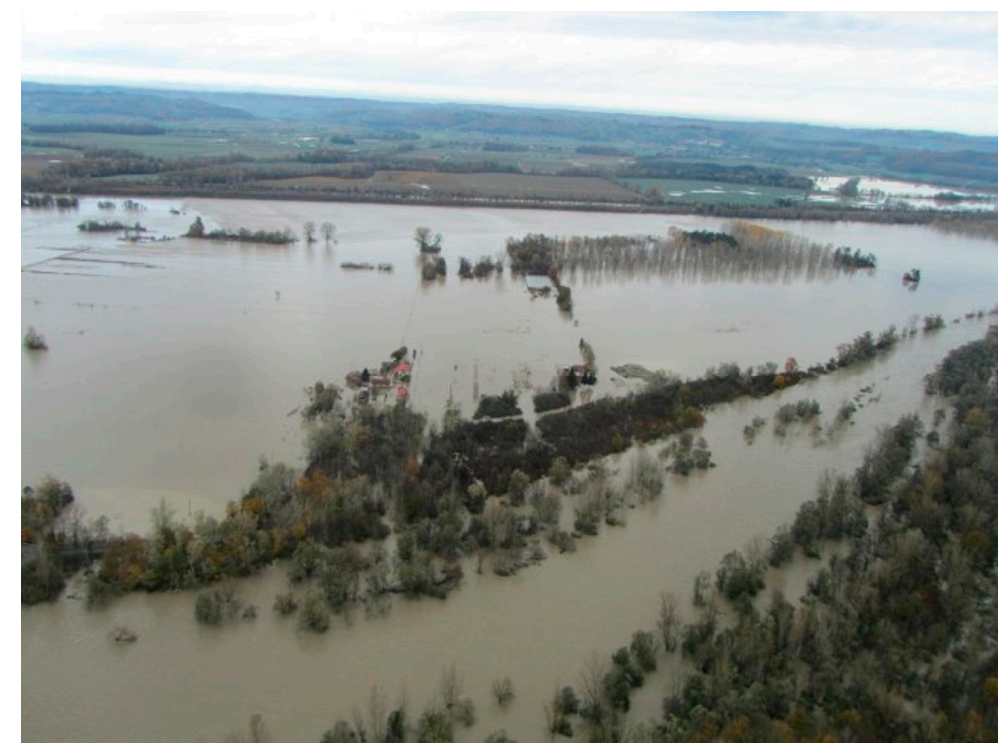

Figure 2. Flood area after breaching Otok Virje-Brezje levee [34].

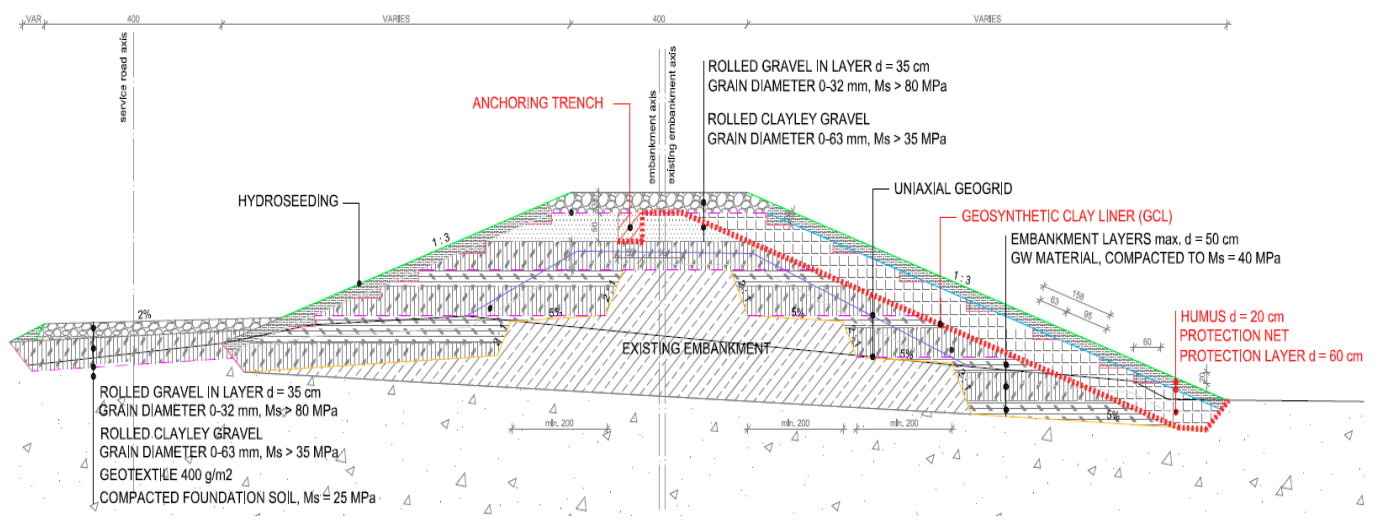

Figure 3. Cross-section of the Otok Virje-Brezje levee proposed in the construction design [34].

\section{Identification of the Key Risks During the Levee Reconstruction Project}

The risk management process begins with risk identification in order to compile a list of key risks related to the project [35]. For every levee reconstruction project, a large number of potential risks can be identified. These are events whose unfavourable outcome may be detrimental to project success during its life cycle. However, it will be very challenging to make a complete list of the risks (particularities of each project) for reconstruction projects of levees, regardless of the size, type and contents. Such a list would contain a certain number of high-exposure risks, including a great number of negligible risks of low-exposure. According to Kovacevic et al. [36], the most common risks during reconstruction of a levee are as follows: overtopping when the water level surpasses the crest of the levee, inundation resulting from the malfunction of the levee components, seeping of the water through the levee, seeping of the water through the foundation soil under the levee, surface erosion of the levee, internal erosion of the levee, rapid drawdown condition, presence of animal burrows, lack of knowledge about the soil conditions due to inadequate site investigation, inadequate monitoring and evaluation of the levee condition, insufficiently detailed reconstruction 
design, unsatisfactory performance of reconstruction works, damage from vessels occurring during levee exploitation, cavitation damage induced failure of spillways and seismic loading.

Decision-makers use various techniques for risk identification; the best-known ones include brainstorming, interviews, questionnaires, the Delphi method, and expert systems [37]. The brainstorming technique was chosen as the most appropriate. It is a meaningful and open discussion in which participants discuss their views on possible sources of risk in the project. They further discuss how uncertainty manifests and how to turn it into risk [38]. Oladokun et al. [39] evaluated construction risk management techniques in developing economies and concluded that brainstorming is the most effective risk identification technique. According to Goble [40], the advantage of brainstorming is the group diversity to generate ideas. These ideas tend to be superior to individually generated ones. Kobo-Greenhut et al. [41] concluded that most risk analysis techniques rely on brainstorming and that structured brainstorming yields better risk identification. To determine the list of key risks, a group of five experts (designer, project manager, project auditor, supervisor, and contractor representative) who were directly involved in the levee reconstruction project was convened. They were all male and of similar age and experience. They brainstormed the following list of key risks related to Otok Virje-Brezje levee reconstruction:

1. Inadequate site investigation;

2. Overtopping;

3. Insufficiently detailed reconstruction design;

4. Unsatisfactory performance of reconstruction works;

5. Inaccurate monitoring and condition evaluation.

The verification of the list of key risks was performed in two steps. The first step was the choice of experts to took part in the verification of the proposed list of key risks. A total of 30 experts took part; they had played an important role in similar projects. This group was composed of seven designers, six project managers, five supervisors, seven contractor representatives, and five university consultants. In the second step, all the experts were given the list of key risks and the structural questionnaire with a single multiple-choice question. The question was, "What do you think of the proposed key risks related to Otok Virje-Brezje levee reconstruction project"? The choices were Acceptable, Satisfactory, Reasonable, Unsatisfactory and Unacceptable. The experts did not know how the key risks had been identified; this question was posed to verify the identification process. The answers are shown in Figure 4. A high degree of consensus had been reached; thus, it was possible to undertake the risk assessment and to determine the risk priority list.

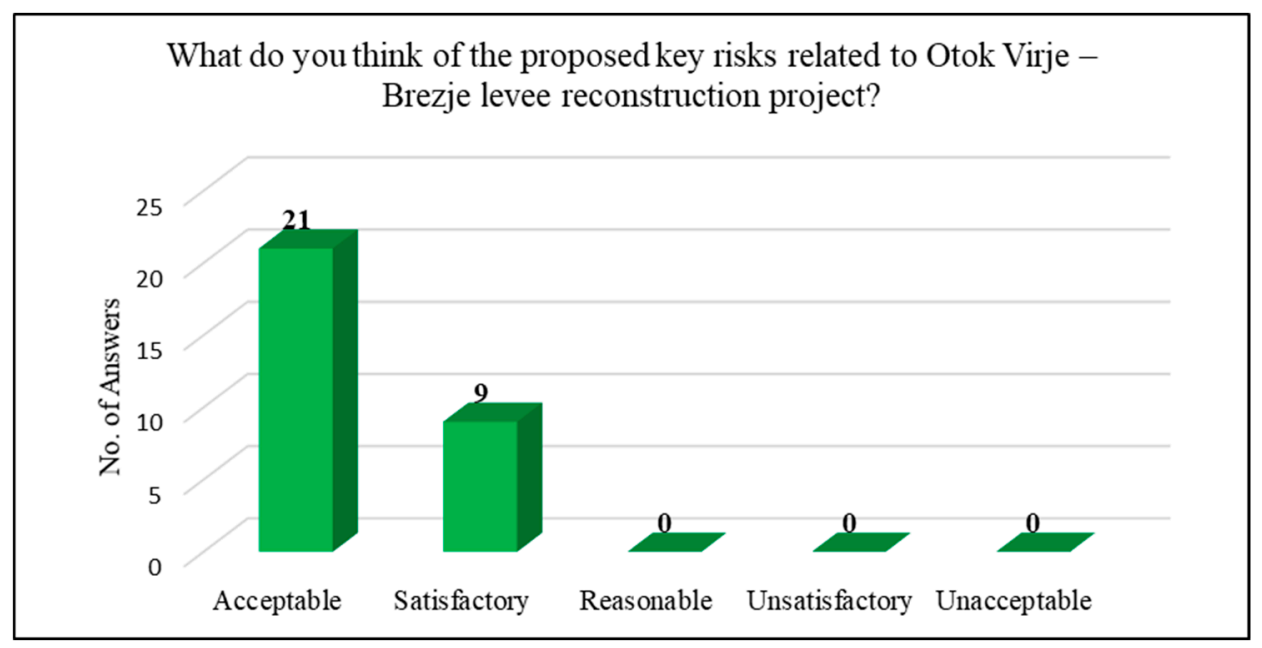

Figure 4. Verification of the list of key risks. 


\section{Risk Assessment in the Levee Reconstruction Project}

Risk assessment is performed by determining risk exposure as a product of risk probability and risk impact. Risk probability is a dimensionless value. The risk may impact time, cost, quality or the environment; its impact can be expressed in monetary units. This means that risk exposure has the dimension of the monetary unit used in calculations. Consequently, risk exposure for a particular risk may acquire any value and is calculated independently. The absolute value of risk exposure for a particular risk, viewed in itself, has practically no usable value. Therefore, it is important to determine how intense the risk exposure of a particular risk is with respect to the risk exposures of the other risks. A priority list is compiled by determining the risk exposures of all the identified risks and placing them in an interrelationship.

The risk priority list can be determined using a quantitative, qualitative or mixed approach. The quantitative approach implies that risk probability and risk impact can be explicitly calculated using one of the known quantitative methods of risk analysis. To do this, the relevant database must be available to form the probability distribution (to enable the direct calculation of the impact on time, cost, quality, and environment) [42-44]. The priority list is created using the qualitative approach when there is no database about earlier projects to use for the probability distribution function and for determining risk probability. Moreover, all the necessary indicators for the direct calculation of the consequences would also be missing for a qualitative approach $[45,46]$. For example, the probability of overtopping can be quantified based on the high-water database in the past, and the probability of inaccurate monitoring and condition evaluation can be quantified from a database about earlier projects. This means that these two probabilities can be compared quantitatively. However, if there is no database about the impact of inadequate site investigation and the insufficiently detailed reconstruction design on the time of reconstruction work execution then these two impacts can only be qualitatively determined. This called for the use of the ANP method.

Thomas L. Saaty developed Analytic Network Process (ANP) to aid managers in in making decisions [47-51]. ANP is one of the methods for multi criteria decision-making. Subjective assessments and objective facts are incorporated into a logical network to provide decision-makers with an intuitive approach in quantifying the importance of each decision element through a comparison process. The ANP method represents a generalisation of the analytic hierarchical process (AHP) to enable decision-makers to reduce the complex problem to a non-linear network form that also contains a linear hierarchical form with several levels. The network consists of clusters and elements or nodes within a cluster. The interaction between the elements of one cluster (inner dependence) and between elements of different clusters (outer dependence) is enabled. Complex real-life problems are well modelled with the interdependence of network elements. Functional interaction between the criteria and alternatives in the model achieves greater stability of the analysis results. Morteza and Tamošaitienè [52] applied the fuzzy ANP to assess the relative importance of risk factors and alternatives and prioritise construction projects. Chatterjee et al. [53] extended the ANP and develop a hybrid multi criteria decision-making model for risk prioritisation during construction. Chou and Ongkowijoyo [54] proposed an ANP-based method to quantify and define the interdependencies among various components of critical infrastructure and their importance based on expert perspectives. The ANP is particularly suitable for flood protection risk assessment. Dano et al. [55] combined ANP with geographic information system (GIS) and remote sensing (RS) derived variables for flood susceptibility assessment and mapping. The ANP model was used to calculate the relative weights of the various flood influencing factors. De Brito et al. [56] concluded that ANP proved to be effective for assessing the vulnerability to floods and that ANP should be used whenever possible as it allows for the capturing of the complex relationships among vulnerability criteria in a transparent way.

The ANP model for risk assessment in the Otok Virje-Brezje levee reconstruction project consists of the main network and two sub-networks (Figure 5). Considering the fact that risk exposure is defined as the product of risk probability and risk impact, the main Risk Exposure network enables the determination of risk exposure while the sub-networks enable the determination of risk probability and 
risk impact. The Risk Probability sub-network contains one criterion: Probability and five alternatives (Site Investigation, Overtopping, Design, Performance, and Monitoring), which are the key risks analysed. The Risk Impact sub-network contains four criteria: Time, Cost, Quality, and Environment, as well as five alternatives. In order to obtain the results (risk exposure) of the ANP model, alternative weight values are multiplied for each alternative in both sub-networks. By normalizing the risk exposure values for all alternatives, the risk priority list was obtained.

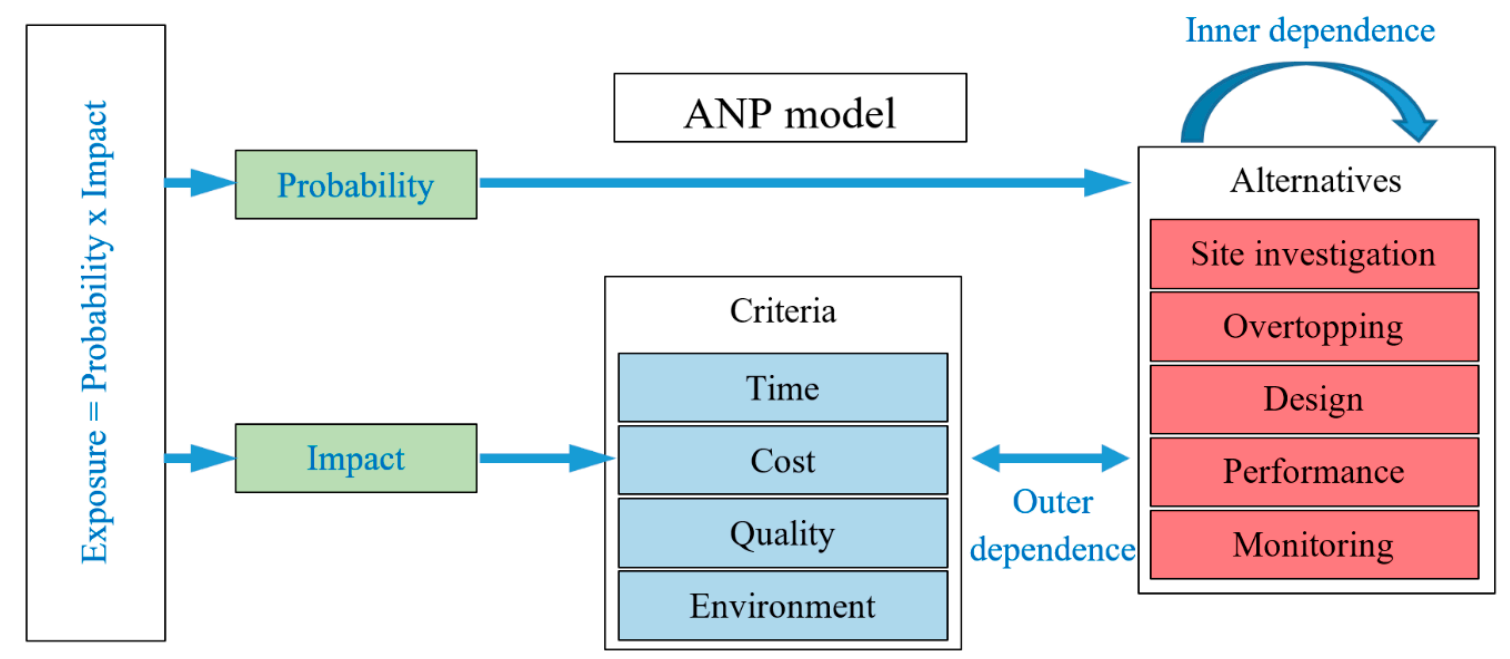

Figure 5. Analytic network process (ANP) model with outer and inner dependence structure.

The model consists of 10 comparisons of the importance of five elements of the Alternatives cluster compared to one element of the Probability cluster, six comparisons of the importance of four elements of the Criteria cluster compared to one element of the Impact cluster, 40 comparisons of the importance of five elements of the Alternatives cluster compared to four elements of the Criteria cluster, 30 comparisons of the importance of the four elements of the Criteria cluster compared to five elements of the Alternatives cluster, and 30 comparisons of the importance of five elements of the Alternatives cluster compared to each one. The modelling was conducted by a total of 35 experts, whereby five verified the key risks and 30 verified that list. The process of comparison is represented by forming a comparison matrix. If the expert has at his disposal $n$ alternatives, or criteria that form the comparison matrix, then he must make $n(n-1) / 2$ evaluations. The eigenvector of each comparative matrix is the priority vector, while the eigenvalue gives the measure of consistency in making the assessment or comparison. The priority vector $W$ and the maximum eigenvalue $\lambda_{\max }$ of the comparison matrix $A$ are determined by solving the general problem of eigenvalues $A W=\lambda_{\max } W$. The consistency coefficients for each comparison matrix at all levels, determined by the eigenvalue of the comparison matrix, and the global consistency coefficients were significantly less than 0.10 . Consistent judgments were therefore made at all hierarchical levels and resulted in 35 risk priority lists. Below are some of the modelling results conducted by the first author of this study, who is also the designer of the Otok Virje-Brezje levee reconstruction.

Table 1 shows a comparison matrix between the relative importance of the elements of the Alternatives cluster and the element of the Probability cluster; relative importance presents an alternative to the Probability, i.e., relative probability of occurrence of each identified key risk. The Site Investigation is three times more likely to occur than the Design. Meanwhile, the Performance is 1.5 times less likely to occur than Monitoring. It is evident that Site investigation is the most likely alternative, and the Design is the least likely. 
Table 1. Comparison of alternatives with respect to Probability.

\begin{tabular}{ccccccc}
\hline Risk & $\begin{array}{c}\text { Site } \\
\text { Investigation }\end{array}$ & Overtopping & Design & Performance & Monitoring & $\begin{array}{c}\text { Priority } \\
\text { Vector }\end{array}$ \\
\hline Site & $1 / 1$ & $1.5 / 1$ & $3 / 1$ & $2 / 1$ & $1,5 / 1$ & 0.316 \\
investigation & $1 / 1.5$ & $1 / 1$ & $2 / 1$ & $1.5 / 1$ & $1 / 1$ & 0.215 \\
Overtopping & $1 / 3$ & $1 / 2$ & $1 / 1$ & $1 / 1$ & $1 / 2$ & 0.115 \\
Design & $1 / 2$ & $1 / 1.5$ & $1 / 1$ & $1 / 1$ & $1 / 1.5$ & 0.139 \\
Performance & $1 / 1.5$ & $1 / 1$ & $2 / 1$ & $1.5 / 1$ & $1 / 1$ & 0.215 \\
Monitoring & & & & & & \\
\hline
\end{tabular}

Table 2 shows a comparison matrix of the relative importance of the elements of the Criteria cluster compared to the elements of the Impact cluster and the obtained importance in comparison to the Impact cluster. In conclusion, Time is three times more important than Quality, and Cost is 2.5 times less important than the Environment. It is evident that Environment is the most important one, with Quality being least important.

Table 2. Comparison of criteria with respect to Impact.

\begin{tabular}{cccccc}
\hline Criteria & Time & Cost & Quality & Environment & Priority Vector \\
\hline Time & $1 / 1$ & $1.5 / 1$ & $3 / 1$ & $1 / 1.5$ & 0.281 \\
Cost & $1 / 1.5$ & $1 / 1$ & $2 / 1$ & $1 / 2.5$ & 0.183 \\
Quality & $1 / 3$ & $1 / 2$ & $1 / 1$ & $1 / 5$ & 0.091 \\
Environment & $1.5 / 1$ & $2.5 / 1$ & $5 / 1$ & $1 / 1$ & 0.445 \\
\hline
\end{tabular}

In order to illustrate the comparison of the alternatives against the criteria, Table 3 shows the comparison matrix of the relative importance of the Alternatives cluster and Environment element of the Criteria cluster. The importance of the alternatives was compared to the Environment criterion. In conclusion, Site Investigation is 4 times more important than Monitoring, and the Design is 2 times less important than Overtopping. Therefore, Overtopping is the most important, and Monitoring is the least important criterion.

Table 3. Comparison of alternatives with respect to the Environment criterion.

\begin{tabular}{ccccccc}
\hline Risk & $\begin{array}{c}\text { Site } \\
\text { Investigation }\end{array}$ & Overtopping & Design & Performance & Monitoring & $\begin{array}{c}\text { Priority } \\
\text { Vector }\end{array}$ \\
\hline $\begin{array}{c}\text { Site } \\
\text { investigation }\end{array}$ & $1 / 1$ & $1.5 / 1$ & $1.5 / 1$ & $7.5 / 1$ & $4 / 1$ & 0.290 \\
Overtopping & $1 / 1.5$ & $1 / 1$ & $2 / 1$ & $10 / 1$ & $5 / 1$ & 0.399 \\
Design & $1 / 1.5$ & $1 / 2$ & $1 / 1$ & $5 / 1$ & $2.5 / 1$ & 0.195 \\
Performance & $1 / 7.5$ & $1 / 10$ & $1 / 5$ & $1 / 1$ & $1 / 2$ & 0.039 \\
Monitoring & $1 / 4$ & $1 / 5$ & $1 / 2.5$ & $2 / 1$ & $1 / 1$ & 0.077 \\
\hline
\end{tabular}

In order to illustrate the comparison of the alternatives against the criteria, Table 4 shows the comparison matrix of the relative importance of the Criteria cluster and Overtopping element of the Alternatives cluster. The importance of the criterion was compared to the Overtopping alternative. Overtopping risk was twice as important as Quality, and Time was five times less important than the Environment. It is evident that the Environment is the most important, and Time is the least important criterion. 
Table 4. Comparison of criteria with respect to the Overtopping alternative.

\begin{tabular}{cccccc}
\hline Criteria & Time & Cost & Quality & Environment & Priority Vector \\
\hline Time & $1 / 1$ & $1 / 4$ & $1 / 3$ & $1 / 5$ & 0.075 \\
Cost & $4 / 1$ & $1 / 1$ & $2 / 1$ & $1 / 1.5$ & 0.319 \\
Quality & $3 / 1$ & $1 / 2$ & $1 / 1$ & $1 / 2$ & 0.195 \\
Environment & $5 / 1$ & $1.5 / 1$ & $2 / 1$ & $1 / 1$ & 0.411 \\
\hline
\end{tabular}

In order to illustrate the comparison of the alternatives against all existing ones, Table 5 shows the comparison matrix of the relative importance of the Alternatives cluster and Performance risk; the importance of the alternatives was compared to the Performance alternative. This example was chosen because, in the ANP model, the Performance risk had the highest importance. In conclusion, Site Investigation is twice as important as Monitoring, and Overtopping is as important as the Design. It is evident that Site Investigation is the most important, and Overtopping is the least important alternative.

Table 5. Comparison of alternatives with respect to the Performance alternative.

\begin{tabular}{cccccc}
\hline Risk & $\begin{array}{c}\text { Site } \\
\text { Investigation }\end{array}$ & Overtopping & Design & Monitoring & Priority Vector \\
\hline Site & $1 / 1$ & $5 / 1$ & $2 / 1$ & $2 / 1$ & 0.457 \\
investigation & $1 / 5$ & $1 / 1$ & $1 / 1$ & $1 / 3$ & 0.109 \\
Overtopping & $1 / 2$ & $1 / 1$ & $1 / 1$ & $1 / 2$ & 0.154 \\
Design & $1 / 2$ & $3 / 1$ & $2 / 1$ & $1 / 1$ & 0.280 \\
Monitoring & & & \\
\hline
\end{tabular}

Figure 6; Figure 7 show the risk probability and risk impact obtained for every risk analysed. Figure 8 shows the risk exposure calculated as the normalized product of risk probability (Figure 6) and risk impact (Figure 7) obtained through the ANP model.

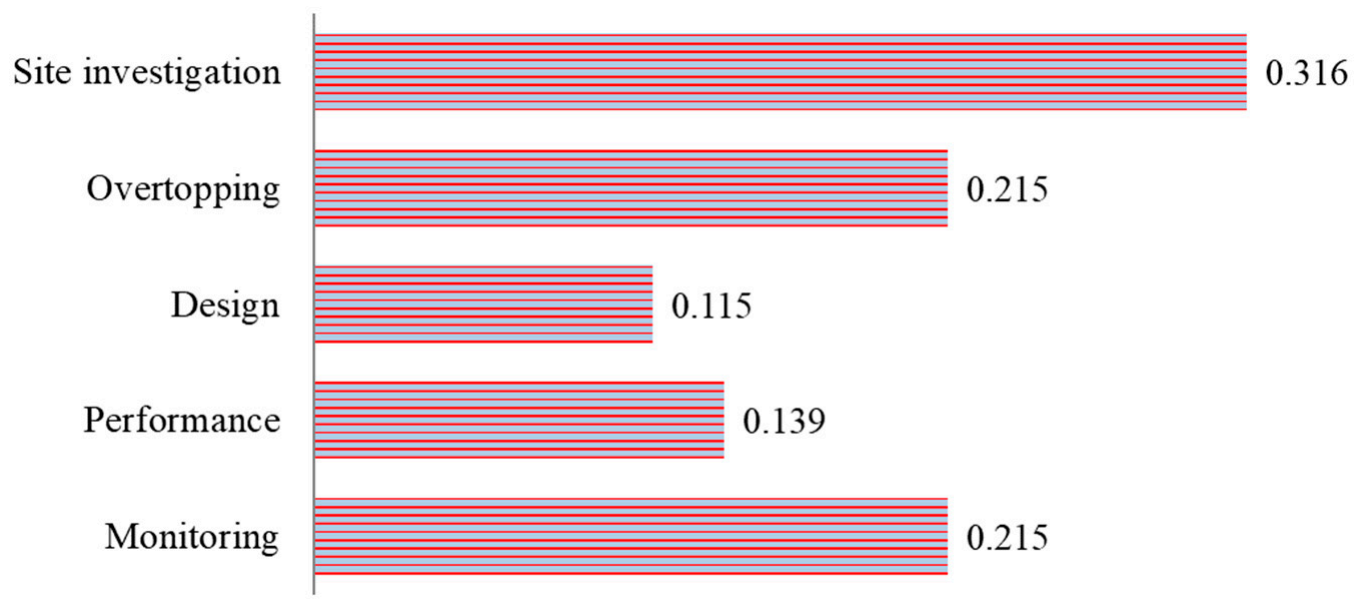

Figure 6. Risk probability for the ANP model. 


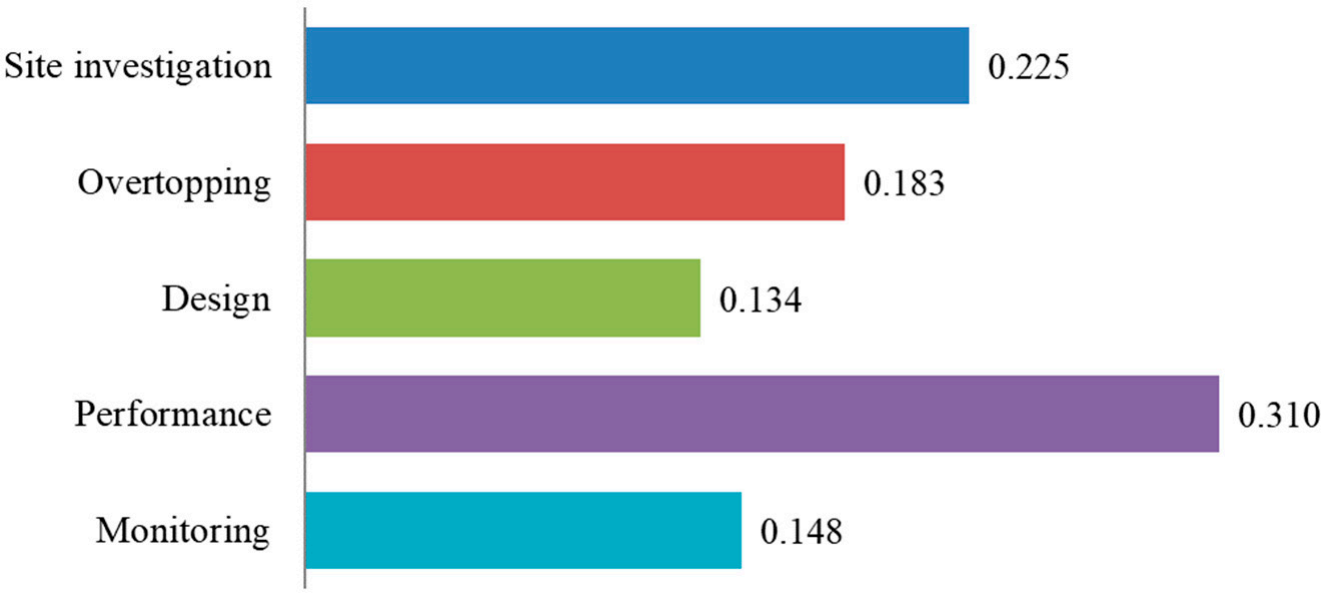

Figure 7. Risk impact for the ANP model.

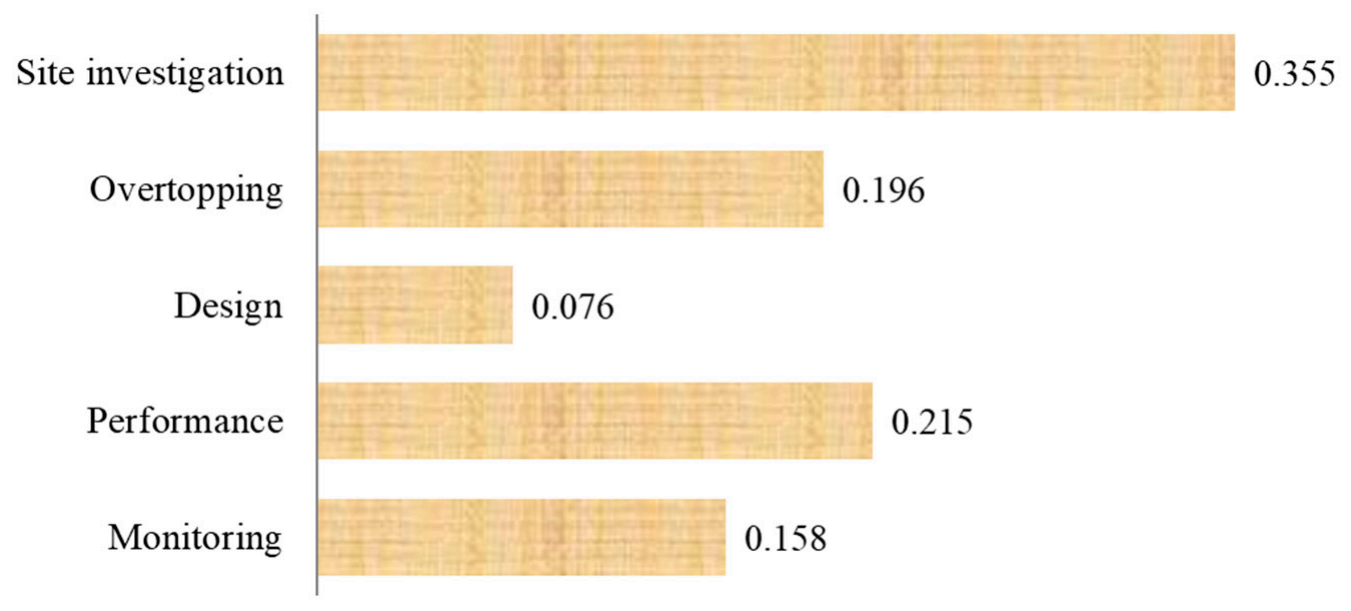

Figure 8. Risk exposure for the ANP model.

\section{Application of Reliability Analysis for Risk Ranking in the Levee Reconstruction Project}

Risk assessment was performed by a group of experts. The result is 35 risk priority lists or 35 sets of individual normalised risk exposures for each key risk (Table 6). Expert 1 is the first author of this study and the designer of the Otok Virje-Brezje levee reconstruction. As can be seen, there are deviations in the priorities of individual experts. For example, the order of risk exposures in the priority list of Expert 25 is different from the order established by the designer. Risk exposures of Overtopping and Performance risks are greater than risk exposure of Site investigation risk, and thus greater resources should be allocated to them. Using the ANP model, Expert 10 obtained the same ranking in the risk priority list, but the differences between the first and second risk exposures are much smaller than those of the designer. 
Table 6. Individual risk exposures.

\begin{tabular}{|c|c|c|c|c|c|}
\hline Expert No. & $\begin{array}{c}\text { Site } \\
\text { Investigation }\end{array}$ & Overtopping & Design & Performance & Monitoring \\
\hline 1 & 0.355 & 0.196 & 0.076 & 0.215 & 0.158 \\
\hline 2 & 0.330 & 0.189 & 0.059 & 0.253 & 0.170 \\
\hline 3 & 0.310 & 0.231 & 0.063 & 0.240 & 0.155 \\
\hline 4 & 0.352 & 0.211 & 0.044 & 0.242 & 0.150 \\
\hline 5 & 0.269 & 0.213 & 0.062 & 0.264 & 0.192 \\
\hline 6 & 0.344 & 0.214 & 0.051 & 0.233 & 0.157 \\
\hline 7 & 0.347 & 0.238 & 0.061 & 0.214 & 0.140 \\
\hline 8 & 0.295 & 0.213 & 0.052 & 0.269 & 0.171 \\
\hline 9 & 0.318 & 0.233 & 0.043 & 0.253 & 0.153 \\
\hline 10 & 0.311 & 0.202 & 0.051 & 0.255 & 0.181 \\
\hline 11 & 0.288 & 0.254 & 0.062 & 0.238 & 0.159 \\
\hline 12 & 0.293 & 0.225 & 0.053 & 0.268 & 0.161 \\
\hline 13 & 0.305 & 0.227 & 0.057 & 0.239 & 0.172 \\
\hline 14 & 0.281 & 0.246 & 0.061 & 0.246 & 0.167 \\
\hline 15 & 0.280 & 0.271 & 0.066 & 0.232 & 0.151 \\
\hline 16 & 0.277 & 0.239 & 0.064 & 0.239 & 0.181 \\
\hline 17 & 0.329 & 0.230 & 0.054 & 0.252 & 0.135 \\
\hline 18 & 0.299 & 0.259 & 0.074 & 0.223 & 0.145 \\
\hline 19 & 0.297 & 0.253 & 0.065 & 0.246 & 0.139 \\
\hline 20 & 0.305 & 0.219 & 0.052 & 0.237 & 0.188 \\
\hline 21 & 0.278 & 0.206 & 0.060 & 0.276 & 0.179 \\
\hline 22 & 0.257 & 0.245 & 0.055 & 0.243 & 0.199 \\
\hline 23 & 0.304 & 0.219 & 0.066 & 0.245 & 0.166 \\
\hline 24 & 0.276 & 0.238 & 0.043 & 0.261 & 0.182 \\
\hline 25 & 0.241 & 0.264 & 0.055 & 0.252 & 0.189 \\
\hline 26 & 0.305 & 0.215 & 0.063 & 0.271 & 0.146 \\
\hline 27 & 0.264 & 0.247 & 0.074 & 0.239 & 0.177 \\
\hline 28 & 0.258 & 0.262 & 0.047 & 0.250 & 0.184 \\
\hline 29 & 0.275 & 0.228 & 0.078 & 0.256 & 0.162 \\
\hline 30 & 0.303 & 0.248 & 0.059 & 0.246 & 0.144 \\
\hline 31 & 0.274 & 0.247 & 0.060 & 0.256 & 0.162 \\
\hline 32 & 0.276 & 0.227 & 0.075 & 0.244 & 0.178 \\
\hline 33 & 0.291 & 0.239 & 0.047 & 0.239 & 0.185 \\
\hline 34 & 0.315 & 0.224 & 0.058 & 0.229 & 0.174 \\
\hline 35 & 0.294 & 0.232 & 0.065 & 0.242 & 0.166 \\
\hline
\end{tabular}

The risk exposures obtained by using the geometric mean method were normalized so that their sum equals to one. The risk exposures are proportional to the resources that will be allocated to the risk responses.

Table 7 shows the aggregated risk priority lists obtained by using the geometric mean method. It shows that more resources should be allocated for management of the Site Investigation risk $(29.7 \%)$, followed by Performance (24.7\%), Overtopping (23.2\%), Monitoring (16.6\%) and lastly Design ( $5.8 \%)$.

Table 7. Risk priority list with related aggregated risk exposures.

\begin{tabular}{cc}
\hline Risk & Risk Exposure \\
\hline Site investigation & 0.297 \\
Performance & 0.247 \\
Overtopping & 0.232 \\
Monitoring & 0.166 \\
Design & 0.058 \\
\hline
\end{tabular}


The reliability analysis of the group consensus-reaching method was conducted by determining the risk ranking probability matrix by using the Monte Carlo simulation method. This method is widely used in risk management and reliability analysis. Namazian et al. [57] used it for assessing completion time of projects under risk. Lan et al. [58] presented an integrated probabilistic framework that combines Monte Carlo simulation and a flood control risk model. Aronica et al. [59] performed the probabilistic evaluation of flood hazard in urban areas using Monte Carlo simulation. The components of the risk ranking probability matrix included the probabilities that the risk exposure of individual risk is less than the risk exposure of other risks. That means that risk exposures are treated as random variables. The analysis starts by forming a probability distribution of the risk exposures on the basis of 35 individual risk exposures for each key risk (Table 6). To avoid making assumptions about the probability distribution of the risk exposures, the kernel distribution was chosen. This is a nonparametric continuous smooth representation of the probability density function (PDF) of a random variable [60]. Figure 9 shows the histogram and kernel probability density functions of random variables Site investigation and Overtopping.
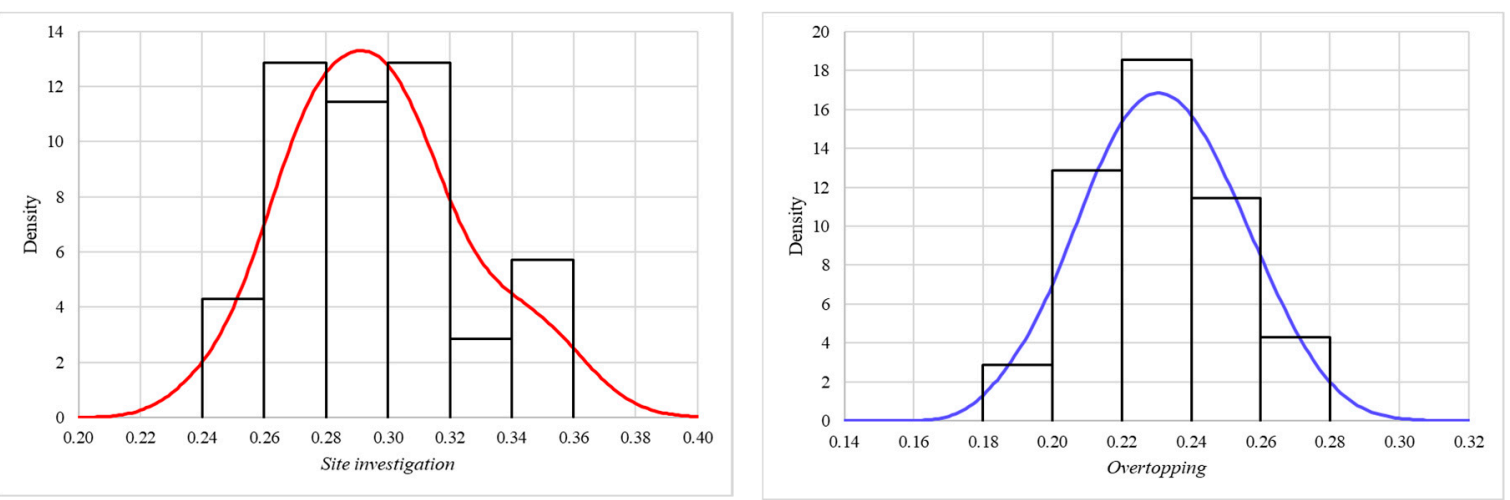

Figure 9. Histogram and kernel probability density function (PDF) of random variables Site investigation and Overtopping.

The probability that the value of the random variable Site investigation is less than the value of the random variable Overtopping is equal to the probability that the difference between the values of the random variables Site investigation and Overtopping is less than zero: $\mathrm{p}_{S-O}=\mathrm{P}[(S-O)<0]$. The difference in random variables is also a random variable $(S-O)$. The probability density function, mean and the standard deviation of a random variable $(S-O)$ will be calculated using the Monte Carlo Simulation method. The reliability index $\beta$ represents the ratio of its mean $\mu_{S-O}$ and the standard deviation $\sigma_{S-O}($ Figure 10).
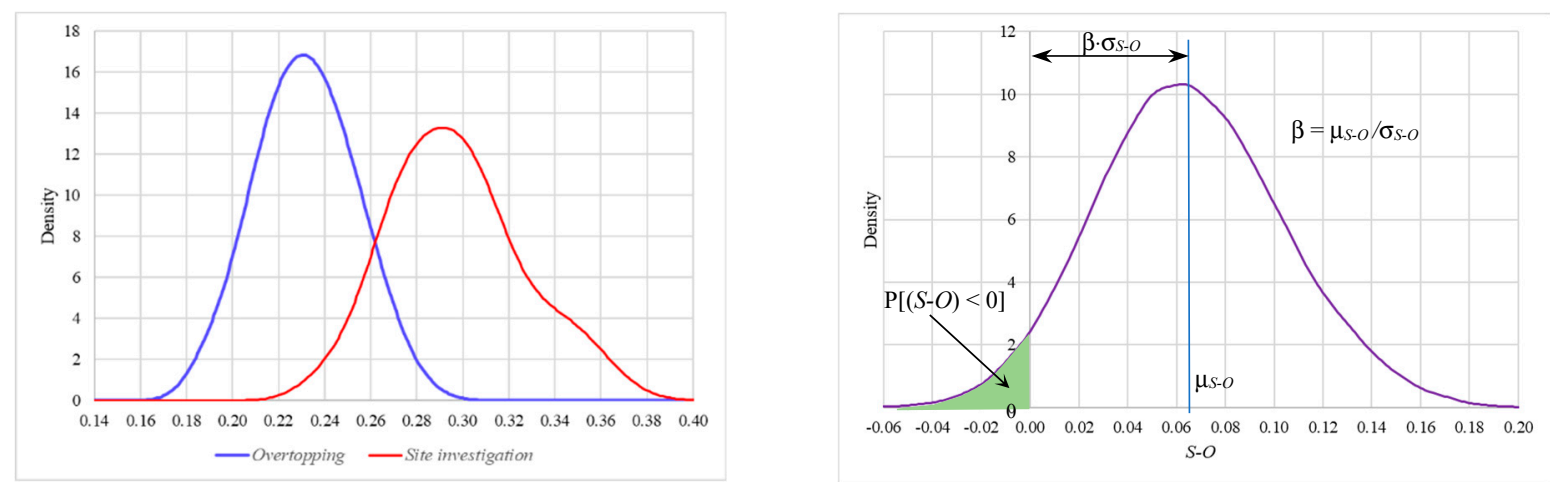

Figure 10. Probability density function of random variable $S-O$. 
In the same way, the probability $\mathrm{p}_{\mathrm{i}-\mathrm{j}}$ for all other key risk combinations can be determined. The result of the reliability analysis is the risk ranking probability matrix (Table 8). It can be seen that $\mathrm{p}_{\mathrm{j}-\mathrm{i}}=1-\mathrm{p}_{\mathrm{i}-\mathrm{j}}$.

Table 8. Risk ranking probability matrix $\left(\mathrm{p}_{\mathrm{i}-\mathrm{j}}\right)$.

\begin{tabular}{cccccc}
\hline Risk & $\begin{array}{c}\text { Site } \\
\text { Investigation }\end{array}$ & Performance & Overtopping & Monitoring & Design \\
\hline Site & N/A & 0.070 & 0.044 & $1676 \mathrm{e}-04$ & $1050 \mathrm{e}-13$ \\
investigation & 0.930 & N/A & 0.302 & $6401 \mathrm{e}-04$ & $2100 \mathrm{e}-18$ \\
Performance & 0.956 & 0.698 & N/A & 0.014 & $1626 \mathrm{e}-12$ \\
Overtopping & 0.999 & 0.999 & 0.986 & N/A & $4613 \mathrm{e}-11$ \\
Monitoring & 1000 & 1000 & 1000 & 1000 & N/A \\
Design & & & & & \\
\hline
\end{tabular}

\section{Discussion}

The application of the ANP method for risk assessment in the levee reconstruction projects results in a ranking of risks according to the value of their risk exposure. Depending on the position of the risk in the risk priority list, or the relative value of its exposure with respect to other risks, appropriate resources will be utilised for the anticipated risk response. Owing to the fact that 35 experts participated in the decision to allocate risk response resources, the geometric mean method was used to determine the risk exposures for each key risk. These risk exposure values were then normalised so that their sum is equal to one. The value of the normalized risk exposure for each key risk is proportional to the resources that will be allocated to the risk responses.

The reliability of using the geometric mean method to reach consensus in decision making was analysed by determining the probability that a lower-ranked risk had a higher risk exposure than a higher-ranked risk. Table 8 shows that the probability that Overtopping and Monitoring risks switch places in the rankings is 0.014 . This means that out of 1000 experts, only 14 of them will give higher priority (and higher risk response) to Design risk over Performance risk. This example indicates high reliability in the allocation of risk response resources. However, the probability of Performance risk and Overtopping risk switch places in the rankings is 0.320 . This means that as many as $30.2 \%$ of the entire expert population will prioritise Overtopping risk over Performance risk. It is therefore difficult to speak of confidence in the consensus reached.

If consensus is not reached with satisfactory reliability, two approaches are possible. The first approach is to apply the Delphi method of reaching consensus, by sending experts the values of normalised risk exposures of key risks obtained by the geometric mean method. After the results of the second round arrive, a new reliability analysis is performed, and the corresponding probabilities are calculated. The rounds are repeated until consensus is reached, or until the highest probability that indicates that the risks of switching places in the rankings is less than some threshold value. It is proposed that this probability be less than 0.05 , which means that for every 100 experts, five of them will have different priorities in the risk ranking.

Another approach is to redistribute risk response resources based on the results of the reliability analysis. This can be achieved by changing the values of the risk exposures shown in Table 7 . Let the risk exposure of lower-ranked risk be $a$ and let the risk exposure of higher-ranked risk be $b$. Let the probability that a lower-ranked risk has a higher risk exposure than a higher-ranked risk be $p$. The risk exposure of the lower-ranked risk should be increased to become $c=a+(b-a) \times p$ and the risk exposure of the higher-ranked risk should be reduced to become $d=b-(b-a) \times p$. The total value of risk exposures for these two risks remains the same because $a+b=c+d$. If all experts have the same preferences, the probability that the two risks will switch places will be $p=0$. No redistribution is made, and the risk exposures remain the same because $c=a$ and $d=b$. If half of the experts assume that more resources are needed to respond to one risk, while the other half assumes that it should be done for the 
other risk, then the probability of the two risks switching places will be $p=0.5$. Reallocations will be made in such a way that equal resources are allocated for both risks. Risk exposures become equal to their arithmetic mean because $c=0.5 \times(a+b)$ and $d=0.5 \times(a+b)$. The reallocation of resources for risk responses is presented in Table 9. It shows that the resources now should be allocated as follows: Site Investigation risk (28.9\%), Performance (24.6\%), Overtopping (24.1\%), Monitoring (16.6\%) and Design $(5.8 \%)$.

Table 9. Risk priority list with new risk exposures.

\begin{tabular}{cc}
\hline Risk & Risk Exposure \\
\hline Site investigation & 0.289 \\
Performance & 0.247 \\
Overtopping & 0.241 \\
Monitoring & 0.166 \\
Design & 0.058 \\
\hline
\end{tabular}

\section{Conclusions}

Floods are natural disasters that cannot be completely prevented. With the continued development of flood protection systems, construction of protective and regulatory water structures, and implementation of flood protection measures, flood risks can be reduced significantly. Owing to climate change, effective and sustainable flood protection has recently become an increasingly important consideration worldwide. The concept of flood protection has traditionally been based on levees. Flood risk management involves a comprehensive approach to reducing the probability of floods and their potential adverse effects on the population, economy and environment. To reduce the risk of flooding, it is necessary to reconstruct and upgrade the existing levees. The identification of key risks, risk assessment and allocation of foreseen risk response resources are presented on the example of the Otok Virje-Brezje levee located in the northwest part of the Republic of Croatia. Owing to a large water wave, the levee collapsed in width of $50 \mathrm{~m}$ and flooded approximately $6.45 \mathrm{~km}^{2}$ of the occupied area.

To identify the key risks as the most appropriate, a brainstorming technique was selected. A group of experts (designer, project manager, project auditor, supervisor, and contractor representative), directly involved in the levee reconstruction project, was selected. The list of the key risks was verified with the help of a group of 30 experts with significant experience in similar projects. It was concluded that a high degree of consensus was reached on the selection of key risks in the levee reconstruction project. Owing to the fact that it was necessary to combine quantitative and qualitative approaches to risk analysis, ANP was chosen as one of the methods for multi criteria decision making. The application of the ANP method helped with the formation of a risk priority list and the allocation of risk response resources in proportion to the value of their risk exposures. A group of 35 experts participated in the risk assessment. The geometric mean method was used to reach consensus in group decision-making. The reliability of using the geometric mean method was analysed by determining the probability that a lower-ranked risk had a higher risk exposure than a higher-ranked risk. The scientific contribution of this manuscript is the development a novel application of reliability analysis for risk ranking in a levee reconstruction project. The research contributes to the development of group multi criteria decision-making methods related to risk contingency measures. It can improve the planning and effective management of levee construction processes.

Author Contributions: Conceptualization, M.S.K. and L.L.; Methodology, A.C.; Validation, L.L., and G.I.; Formal analysis, L.L. and G.I.; Investigation, M.S.K. and L.L.; Writing-original draft preparation, M.S.K. and L.L.; Writing-review and editing, A.C. All authors have read and agreed to the published version of the manuscript.

Funding: This research received no external funding.

Acknowledgments: Authors gratefully acknowledge the support from the H2020 Programme for oVERFLOw project, funded under UCPM-INT-AG Union Civil Protection Mechanism, grant agreement No 874421. 
Conflicts of Interest: The authors declare no conflict of interest.

\section{References}

1. Mathud, D.K.; Udan, P.M. Application of Remote Sensing and GIS for Flood Vulnerability and Mitigation: A Case Study of Flood Affected Villages of Mahi River. Arch. Phys. Res. 2017, 8, 7-11.

2. Jongman, B.; Ward, P.J.; Aerts, J.C.J.H. Global exposure to river and coastal flooding: Long term trends and changes. Global Environ. Chang. 2012, 22, 823-835. [CrossRef]

3. Alfieri, L.; Burek, P.; Feyen, L.; Forzieri, G. Global warming increases the frequency of river floods in Europe. Hydrol. Earth Syst. Sci. 2015, 19, 2247-2260. [CrossRef]

4. Arnell, N.W.; Gosling, S.N. The impacts of climate change on river flood risk at the global scale. Clim. Chang. 2016, 134, 387-401. [CrossRef]

5. Kron, W.; Löw, P.; Kundzewicz, Z.W. Changes in risk of extreme weather events in Europe. Environ. Sci. Policy 2019, 100, 74-83. [CrossRef]

6. Hui, R.; Jachens, E.; Lund, J. Risk-based planning analysis for a single levee. Water Resour. Res. 2016, 52, 2513-2528. [CrossRef]

7. Bacic, M.; Kovacevic, M.S.; Libric, L. Implementation of Eurocode 7 in the design of flood protection embankments in Croatia. In Proceedings of the 15th International Symposium on Water Management and Hydraulics Engineering, Primosten, Croatia, 6-8 September 2017; Bekic, D., Carevic, D., Vouk, D., Eds.; Faculty of Civil Engineering: Zagreb, Croatia, 2017; pp. 214-223.

8. Ravnjak, K.; Grget, G.; Kovacevic, M.S. Levees condition assessment in Croatia. In Road and Rail Infrastructure IV, Proceedings of the Conference CeTRA 2016, Sibenik, Croatia, 23-25 May 2016; Lakusic, S., Ed.; Department of Transportation, Faculty of Civil Engineering: Zagreb, Croatia, 2016; pp. 535-539.

9. Libric, L.; Kovacevic, M.S.; Ivos, G. Determining of risk ranking for Otok Virje-Brezje levee reconstruction. In Proceedings of the 2nd International Conference on Natural Hazards \& Infrastructure, Chania, Greece, 23-26 June 2019.

10. Winsemius, H.C.; Van Beek, L.P.H.; Jongman, B.; Ward, P.J.; Bouwman, A. A framework for global river flood risk assessments. Hydrol. Earth Syst. Sci. 2013, 17, 1871-1892. [CrossRef]

11. Klijn, F.; Kreibich, H.; de Moel, H.; Penning-Rowsell, E. Adaptive flood risk management planning based on a comprehensive flood risk conceptualisation. Mitig. Adapt. Strateg. Global Chang. 2015, 20, 845-864. [CrossRef]

12. Muis, S.; Güneralp, B.; Jongman, B.; Aerts, J.C.J.H.; Ward, P.J. Flood risk and adaptation strategies under climate change and urban expansion: A probabilistic analysis using global dana. Sci. Total Environ. 2015, 538, 445-457. [CrossRef]

13. ISO 31010. Risk Management_Risk Assessment Techniques; ISO: Geneva, Switzerland, 2019.

14. Ceric, A.; Marcic, D.; Kovacevic, M.S. Applying the analytic network process for risk assessment in sustainable ground improvement. Građevinar 2013, 65, 919-929. [CrossRef]

15. Mihalinec, Z.; Bacic, M.; Kovacevic, M.S. Risk identification in landslide monitoring. Građevinar 2013, 65, 523-536. [CrossRef]

16. Lupton, D. Introduction: Risk and sociocultural theory. In Risk and Sociocultural Theory: New Directions and Perspectives; Lupton, D., Ed.; Cambridge University Press: Cambridge, UK, 2009; pp. 1-11. [CrossRef]

17. Ceric, A.; Marcic, D.; Ivandić, K. A risk-assessment methodology in tunnelling. Teh. Vjesn. 2011, 18, 529-536.

18. Mohd, W.R.W.; Abdullah, L. Aggregation methods in group decision making: A decade survey. Informatica 2017, 41, 71-86.

19. Liao, H.C.; Xu, Z.S.; Zeng, X.J.; Xu, D.L. An enhanced consensus reaching process in group decision making with intuitionistic fuzzy preference relations. Inf. Sci. 2016, 329, 274-286. [CrossRef]

20. Xu, X.H.; Du, Z.J.; Chen, X.H. Consensus model for multi-criteria large-group emergency decision making considering non-cooperative behaviors and minority opinions. Decis. Support Syst. 2015, 79, 150-160. [CrossRef]

21. Kosovac, A.; Davidson, B.; Malano, H. Are We Objective? A Study into the Effectiveness of Risk Measurement in the Water Industry. Sustainability 2019, 11, 1279. [CrossRef]

22. Dong, Q.X.; Cooper, O. A peer-to-peer dynamic adaptive consensus reaching model for the group AHP decision making. Eur. J. Oper. Res. 2016, 250, 521-530. [CrossRef] 
23. Palomares, I.; Martínez, L.; Herrera, F. A consensus model to detect and manage noncooperative behaviors in large-scale group decision making. IEEE Trans. Fuzzy Syst. 2014, 22, 516-530. [CrossRef]

24. Fu, C.; Yang, J.B.; Yang, S.L. A group evidential reasoning approach based on expert reliability. Eur. J. Oper. Res. 2015, 246, 886-893. [CrossRef]

25. Yager, R.R. On Ordered Weighted Averaging Aggregation Operators in Multicriteria Decision Making. IEEE Trans. Syst. Man Cybern. 1988, 18, 183-190. [CrossRef]

26. Chiclana, F.; Herrera-Viedma, E.; Herrera, F. The Ordered Weighted Geometric Operator: Properties and Applications in MCDM Problems. Technol. Constr. Intell. Syst. 2002, 2, 173-183.

27. Xu, Z.S. Harmonic Mean Operator for Aggregating Linguistic Information. In Proceedings of the Fourth International Conference on Natural Computing, Jinan, China, 18-20 October 2008; Guo, M., Liang, Z., Wang, L., Eds.; IEEE Computer Society: Washington, DC, USA, 2008; pp. 204-208. [CrossRef]

28. Fan, C.; Ye, J.; Hu, K.; Fan, E. Bonferroni Mean Operators of Linguistic Neutrosophic Numbers and Their Multiple Attribute Group Decision-Making Methods. Information 2017, 8, 107. [CrossRef]

29. Yager, R.R. The Power Average Operator. IEEE Trans. Syst. Man Cybern. 2001, 31, 724-731. [CrossRef]

30. Angilella, S.; Greco, S.; Matarazzo, B. Non-Additive Robust Ordinal Regression: A Multiple Criteria Decision Model Based on the Choquet Integral. Eur. J. Oper. Res. 2010, 201, 277-288. [CrossRef]

31. Dubois, D.; Prade, H.; Rico, A. Residuated Variants of Sugeno Integrals: Towards New Weighting Schemes for Qualitative Aggregation Methods. Inf. Sci. 2016, 329, 765-781. [CrossRef]

32. Merigo, J.M.; Casanovas, M. Fuzzy Generalized Hybrid Aggregation Operators and Its Application iIn Fuzzy Decision Making. Int. J. Fuzzy Syst. 2010, 1, 15-23. [CrossRef]

33. Aczel, J.; Saaty, T.L. Procedures for synthesizing ratio judgments. J. Math. Psychol. 1983, 27, 93-102. [CrossRef]

34. Kovacevic, M.S. Reconstruction of Embankment Virje Otok—Brezje-Main Design; GLP-110-044/2015; Faculty of Civil Engineering, University of Zagreb: Zagreb, Croatia, 2015.

35. Mihic, M.; Ceric, A.; Zavrski, I. Developing Construction Hazard Database for Automated Hazard Identification Process. Teh. Vjesn. 2018, 25, 1761-1769. [CrossRef]

36. Kovacevic, M.S.; Juric Kacunic, D.; Libric, L.; Bacic, M. Risk Assessment in Reconstruction of Flood Protection Embankments Due to Climate Change. In Proceedings of the 16th Danube-European Conference on Geotechnical Engineering, Skopje, Macedonia, 7-9 June 2018. [CrossRef]

37. Ceric, A.; Maric, T. Determining priorities for managing risk on construction projects. Građevinar 2011, 63, 265-271.

38. Seeber, I.; de Vreede, G.J.; Maier, R.; Weber, B. Beyond Brainstorming: Exploring Convergence in Teams. J. Manag. Inf. Syst. 2018, 34, 939-969. [CrossRef]

39. Oladokun, M.G.; Adelakun, A.D.; Ashimolowo, D.O. Evaluation of Construction Risk Management Techniques in Developing Economies: A Case of Nigeria. PM World J. 2016, 5, 1-15.

40. Gobble, M.M. The Persistence of Brainstorming. Res. Technol. Manag. 2014, 57, 64-67. [CrossRef]

41. Kobo-Greenhut, A.; Reuveni, H.; Shlomo, I.Z.; Megnez, R. Unstructured brainstorming is not enough: Structured brainstorming based on four verification and validation questions yields better hazard identification in healthcare. Int. J. Qual. Health Care 2019, 31, 16-21. [CrossRef]

42. Birkmann, J.; Welle, T. Assessing the risk of loss and damage: Exposure, vulnerability and risk to climate related hazards for different country classifications. Int. J. Global Warm. 2015, 8, 191-212. [CrossRef]

43. Agrawal, N. Disaster Risk Evaluation-Other Quantitative Methods. In Natural Disasters and Risk Management in Canada. Advances in Natural and Technological Hazards Research; Springer: Dordrecht, The Netherlands, 2018; Volume 49, pp. 271-293. [CrossRef]

44. Lyu, H.; Shen, S.; Zhou, A.; Yang, Y. Perspectives for flood risk assessment and management for mega-city metro system. Tunn. Undergr. Space Technol. 2019, 84, 31-44. [CrossRef]

45. Gallina, V.; Torresan, S.; Critto, A.; Sperotto, A.; Glade, T.; Marcomini, A. A review of multi-risk methodologies for natural hazards: Consequences and challenges for a climate change impact assessment. J. Environ. Manag. 2016, 168, 123-132. [CrossRef]

46. Scorzini, A.R.; Leopardi, M. River basin planning: From qualitative to quantitative flood risk assessment: The case of Abruzzo Region (central Italy). Nat. Hazards 2017, 88, 71-93. [CrossRef]

47. Saaty, T.L. Fundamentals of the analytic network process: Dependence and feedback in decision-making with a single network. J. Syst. Sci. Syst. Eng. 2004, 13, 129-157. [CrossRef] 
48. Saaty, T.L. Theory and Applications of the Analytic Network Process; RWS Publications: Pittsburgh, PA, USA, 2005.

49. Saaty, T.L. Rank from comparisons and from ratings in the analytic hierarchy/network processes. Eur. J. Oper. Res. 2006, 168, 557-570. [CrossRef]

50. Saaty, T.L. Time dependent decision-making; dynamic priorities in the AHP/ANP: Generalizing from points to functions and from real to complex variables. Math. Comput. Model. 2007, 46, 860-891. [CrossRef]

51. Saaty, T.L. The analytic network process. Iran. J. Oper. Res. 2008, 1, 1-27.

52. Hatefi, S.M.; Tamošaitienè, J. An integrated fuzzy DEMATEL-fuzzy ANP model for evaluating construction projects by considering interrelationships among risk factors. J. Civ. Eng. Manag. 2019, 25, 114-131. [CrossRef]

53. Chatterjee, K.; Zavadskas, E.K.; Tamošaitienė; JAdhikary, K.; Kar, S. A hybrid MCDM technique for risk management in construction projects. Symmetry 2018, 10, 46. [CrossRef]

54. Chou, J.; Ongkowijoyo, C.S. Hybrid decision-making method for assessing interdependency and priority of critical infrastructure. Int. J. Disaster Risk Reduct. 2019, 39, 101134. [CrossRef]

55. Dano, U.L.; Balogun, A.L.; Matori, A.N.; Wan Yusouf, K.; Abubakar, I.R.; Said Mohamed, M.A.; Aina, Y.A.; Pradhan, B. Flood Susceptibility Mapping Using GIS-Based Analytic Network Process: A Case Study of Perlis, Malaysia. Water 2019, 11, 615. [CrossRef]

56. De Brito, M.M.; Evers, M.; Almoradie, A.D.S. Participatory flood vulnerability assessment: A multi-criteria approach. Hydrol. Earth Syst. Sci. 2018, 22, 373-390. [CrossRef]

57. Namazian, A.; Yakhchali, S.H.; Yousefi, V.; Tamošaitienè, J. Combining Monte Carlo simulation and Bayesian networks methods for assessing completion time of projects under risk. Int. J. Environ. Res. Public Health 2019, 16, 5024. [CrossRef]

58. Lan, Y.; Gui, F.; Luo, D.; Zou, Y.; Bai, H. Study on Flood Control Safety Evaluation Based on Composite Risk Model. Nat. Hazards Earth Syst. Sci. 2019. [CrossRef]

59. Aronica, G.T.; Franza, F.; Bates, P.D.; Neal, J.C. Probabilistic evaluation of flood hazard in urban areas using Monte Carlo simulation (with uncertainty). Hydrol. Process. 2012, 26, 3962-3972. [CrossRef]

60. Zinde-Walsh, V. Kernel Estimation When Density May Not Exist: A Corrigendum. Econom. Theory 2017, 33, 1259-1263. [CrossRef] 